\title{
Cooperation and Innovation-Prospect of Engineering Management Specialty
}

\author{
Qihui Zhao \\ School of civil engineering \\ Xi Jing University \\ Xi'an 710123
}

\author{
Jianfeng Li \\ School of civil engineering \\ Xi Jing University \\ Xi'an 710123
}

\author{
Lulu Hao \\ School of civil engineering \\ Xi Jing University \\ Xi'an 710123
}

\begin{abstract}
For the project management in the development of professional, enhance the management efficiency of project need professional project management personnel of project management, the existing training programs and economic and social development in China still has some distance. Through the discussion on the cultivation of professional engineering management program for the United States and China's current project management professional training program, summed up the characteristics of the training of engineering management specialty, and the future development of Engineering Management Specialty in China and puts forward the school enterprise cooperation project management professional talents should be combined with the new BIM software technology advice.
\end{abstract}

Keywords-engineering management; Development; BIM technology

\section{INTRODUCTION}

Since the reform and opening up, Chinese's economy maintained a rapid and stable development, civil engineering as an important factor of economic growth in China, its development and its relevant personnel in the rapid increase of scale. In our country "along the way" policy under the guidance of China's construction industry is also out of the country, all over the world for the construction of infrastructure facilities, so professional and technical personnel for the project management has put forward more urgent demand. From the engineering management professional personnel present employment situation can be seen, most of the project management professionals play an important role in their respective projects, there is the problem of incomplete knowledge structure and different types of professional cooperation is not harmonious problem. To further improve the training program of engineering management major is of great significance for improving the employment rate of engineering management majors and giving full play to the role of project management personnel in the construction of engineering projects[1].
In the training of engineering management professionals, China and the United States are basically the same. The study of American engineering management courses plays an important role in improving and promoting the personnel training of Engineering Management Specialty in china.

\section{DEVELOPMENT OF ENGINEERING MANAGEMENT MAJOR ABROAD}

As an interdisciplinary discipline, both the United States and China have emphasized that engineering management is a systematic, comprehensive and complex discipline. In the teaching development plan formulated by ACCE in the United States, the training program of engineering management specialty is defined as a technical discipline for the application of complex knowledge structure such as technology, economy and management. Specifically, the United States project management professional training program has the following characteristics[2]:

Engineering Management in the United States is a discipline dominated by construction technology. In the United States, many university programs include five basic courses: basic education, mathematics and science, building construction, construction science, and economic management. There are some relations between the five major courses and the training program of domestic engineering management major. As shown in table 1 .

Construction occupies higher credit and class hours, and most schools have three courses, namely, construction, construction, science and economic management. But the hours and credits of construction and construction science are greater than the course in economic management. 
TABLE I. CURRICULUM CLASSIFICATION AND CREDIT REQUIREMENTS FOR ENGINEERING MANAGEMENT MAJORS IN THE UNITED STATES AND CHINA

\begin{tabular}{|c|c|c|c|}
\hline \multicolumn{2}{|c|}{$\begin{array}{l}\text { The classification and credit requirements of engineering management courses } \\
\text { in the United States }\end{array}$} & \multicolumn{2}{|c|}{$\begin{array}{l}\text { Classification and teaching requirements of engineering } \\
\text { management major in China }\end{array}$} \\
\hline Course classification & Basic credit requirements $\Phi$ & $\begin{array}{l}\text { Course } \\
\text { classification }\end{array}$ & Basic hours requirements \\
\hline Basic education & 15credit & \multirow{2}{*}{ basic course } & \multirow{2}{*}{ 1200class hour } \\
\hline Mathematics and Science & 15credit & & \\
\hline $\begin{array}{l}\text { Building construction } \\
\text { category }\end{array}$ & 18credit & \multirow{3}{*}{$\begin{array}{l}\text { Platform course+ } \\
\text { Orientation course }\end{array}$} & \multirow{4}{*}{ 900class hour+200class hour } \\
\hline Architectural Science & 20credit & & \\
\hline Economic management & 30credit & & \\
\hline Other credits & 22credit & & \\
\hline Total credits(class hour) & 120credit & & 2300class hour \\
\hline
\end{tabular}

The curriculum of core knowledge is comprehensive and extensive. The specialized courses in American colleges and universities include such courses as construction management, civil construction technology, construction site planning, civil engineering drawing, engineering cost and resource allocation. The opening of these courses plays an extremely important role in training a comprehensive engineering management staff.

Professional knowledge combined with field practice. American colleges and universities are very important to the field practice of Engineering Management. In the early twentieth Century, the American pragmatic educational theory put forward the viewpoint of cooperative education from "learning by doing" and "combining education with reeducation through labor". Reasonable and perfect teaching practice is beneficial to enrich the training program of engineering management specialty and improve the ability of engineering management students to adapt to society.

\section{DEVELOPMENT STATUS OF DOMESTIC ENGINEERING MANAGEMENT SPECIALTY}

The research method of engineering management specialty is the combination of engineering technology and scientific management theory, which needs the specific background of the construction industry and technical knowledge. The former Ministry of construction in 1999 to develop the "project management professional training plan" pointed out that the project management professional training objectives is "training with the civil engineering technology and engineering management related management, economic and legal knowledge, access to basic training of engineers with practical and innovative abilities of senior engineering management personnel[3]".

From the history and current situation of project management professional development in our country, the development of engineering management major has experienced a shift from simple civil engineering management knowledge for project management as a broad sense.
Nowadays, 121 colleges and universities have set up engineering management major in our country.

But from the results of some investigations, there are still some problems in the current engineering management education. The personnel training of engineering management should face the needs of engineering practice and society. It is not only the urgent need of the future economic development of our country, but also the experience of foreign engineering management education. The existing graduates of Engineering Management in our country lack the ability to solve practical problems. After related enterprises, it usually takes a long time to adapt to the actual work.

\section{The FUtURE OF ENGINEERING MANAGEMENT}

For the future of engineering management professional education of our country, while retaining the engineering economic laws and regulations foundation engineering and project management courses, to further strengthen the core technology course content[4] from the breadth and depth. Especially in the study of civil engineering construction course, as far as possible to fully understand the project construction project construction stage, and increased with the cooperation between enterprises, let the students to enter the actual project site construction method of learning, understanding in different stages of construction more intuitive.

In addition, project management professional training should be combined with the development of new things, the rapid development of computer technology, the construction industry has been greatly improved, a construction project to show from the original traditional hand-painted, gradually by the computer aided design (CAD) or the drawing software (T20) replaced. The construction industry has also created its own era, greatly improving the efficiency of design and drawing. Then, with the development and application of three dimensional information technology. 3D technology has also been widely used in the construction industry. But this is only in the design to provide convenience, and can't solve the construction process of the budget and civil engineering 
applications in different directions. BIM was created under such conditions and was rapidly used extensively in the construction industry. The following are the features of BIM software:

BIM itself can visualize the data, and automatically import data into the building model, which is more intuitive. This technique is of great help to the construction management, especially in the design phase of the building.

BIM contains all the useful data in the project, and the relevant personnel can draw data directly through the model.
At the same time, the actual construction process, the design of the project is constantly adjusted and improved, and the relevant professionals can adjust the design drawings accordingly through the construction process changes. Greatly improve the efficiency of construction management.

The application of BIM technology in construction projects reflects the innovation and progress of construction technology of construction projects, and also reflects the scientific development of our production methods, and is conducive to the long-term development of the construction industry. Table 2 describes the related software features of BIM.

TABLE II. BIM RELATED SOFTWARE FUNCTIONS

\begin{tabular}{ccc}
\hline Software name & Major tasks in the project & Function at work \\
\hline Revit2016 & Model establishment & Visual effects engineering budget estimate, budget, \\
settlement & Model collision test & Dynamic display and collision detection \\
Navisworks & Detail handling of construction drawings & Drawing adjustment \\
AutoCAD 2007 & Construction simulation & scheduled plan
\end{tabular}

Traditional two-dimensional drawings, manual calculation, the total cost of the project $50 \%-70 \%$. In today's engineering calculation software, such as Glodon, Luban and Revit, the software has been included in every area of our country and the quota standard. Compared to the manual calculation, it has greatly reduced the error rate and saved the cost of the staff's time and energy.

\section{CONCLUSION}

In "along the way" policy driven, China needs to project construction of huge scale, but China's current project management department also has more prominent issues, such as the construction cost, completion of operation quality can't be guaranteed. It is necessary for a large number of engineering management professionals to improve the management ability of engineering projects. The existing training system of Engineering Management in China still has a certain distance with the development of economy and society in china. By studying the training plan of Engineering Management Specialty in our country, the educational level of engineering management specialty can be promoted from 5 aspects. Give full play to the advantages of universities, reasonable positioning of the target of running a school; to strengthen the project management professional core course content from the breadth and depth of expertise; combined with the practice, improve the students' engineering ability to adapt to society; clear training objectives, combined with the development of the times; and by means of reforming the teaching method of project management.

\section{REFERENCES}

[1] He Jishan, Chen Xiaohong, Hong Kairong. On engineering management China [J]. Engineering Science, 2005, (10): 5-10.

[2] Zhang Yajie, Liu Juan Yu. Comparative analysis of Sino US engineering management education system [J]. Shanxi architecture, 2009, (26):200201.

[3] Wang Wang, Wang Nengmin. Current situation and development of engineering management discipline in China [J]. China Engineering Science, 2006, (03): 11-17.

[4] Li, Xing su. Consideration of training program for undergraduate course of engineering management specialty [J]. project management technology, 2008, (10):68-71. 